\title{
教育講演
}

\section{2. 非侵襲的脳機能画像法による脳機能診断}

\section{福山 秀直}

Key words : neuroimaging, MRI, DTI, PET

\section{はじめに}

ヒト脳の局所機能解明の研究は, 臨床兆候の 観察と神経病理学的所見の対比から始まった. このような研究の端緒となったのが，19 世紀に Brocaが失語症の症例の脳の損傷部位を言語中枢 として発表したところに始まる。このような神 経病理学を基礎とした脳機能局在の研究は, 20 世紀の中頃まで続いたが, 1940 年代, Penfield とJaspersにより, 脳外科手術中の脳の電極刺激 によってヒトの局所の運動感覚が脳の運動野, 体性感覚野と関連していることが解明され，ホ ムンクルスと呼ばれる脳表面に体の各部位の地 図を作成することに成功した。これは，体性感 覚と運動に関連する部位の局所分布を中心溝の 前後した部位に図にしたものである。その後, このような脳の機能分布の局在を解明すること， また，その局在の相互のつながりを明らかにす ることが，脳研究の重要な課題となったが，ヒ トでは容易に行うことができるものではないの で, 主にサルを使った研究が主流を占めてきた. サルの場合, 慢性的な電極の埋め込みが可能で, また，ヒトに近い行動をトレーニングで習得さ せることができるため，脳機能の解明にこのよ うな研究手法が多いに用いられた。本研究方法

ふくやま ひでな拉：京都大学医学研究科附属高次脳 機能総合研究センター
は，最近でも盛んで，ミラーニューロンの発見 など神経科学の発展に大きく寄与している。

一方, 1890 年, Roy \& Sherrington ${ }^{1)}$ は, 局所 脳血流と神経活動の密接な関連性を研究し, 神 経活動を直接見るかわりに，脳血流の変化を見 ることで神経活動の様子を推定できることを示 した.これを neurovascular couplingと呼んでい る.これは簡単に言うと, 脳血流を計測すれば, 神経活動を推定できるということになる．現在 でも, ヒト脳の機能局在の研究はこの仮説に則っ て行われている。約 100 年以上前からの考えに 基づいて，研究が行われていることになる.

さらに, 近年の画像診断機器の発展と画像処 理技術の進歩によって，ヒトの脳の機能とその 相互関連を生体から直接観察することが可能に なった. 1970 年にX線CT (computed tomography)が発明され, その端緒となった. 現在の種々 の画像診断装置もその原理自体はCTに基づいた もので, 2 次元あるいは, さらに進んだ 3 次元画 像から，多くの生体情報を得ることができるよ うになった，脳は動くことが少なく，画像化す るのに適した臓器でもあるため，まず，多くの 画像診断機器が脳を検索対象として開発が進め られてきた．現在，脳の形態のみならず，種々 の生理学的・病態学的情報を脳外から測定 - 定 量することができるようになりつつあり, 一種 のバイオマーカーのように特異な所見を示す疾 患も珍しくなくなってきた. 


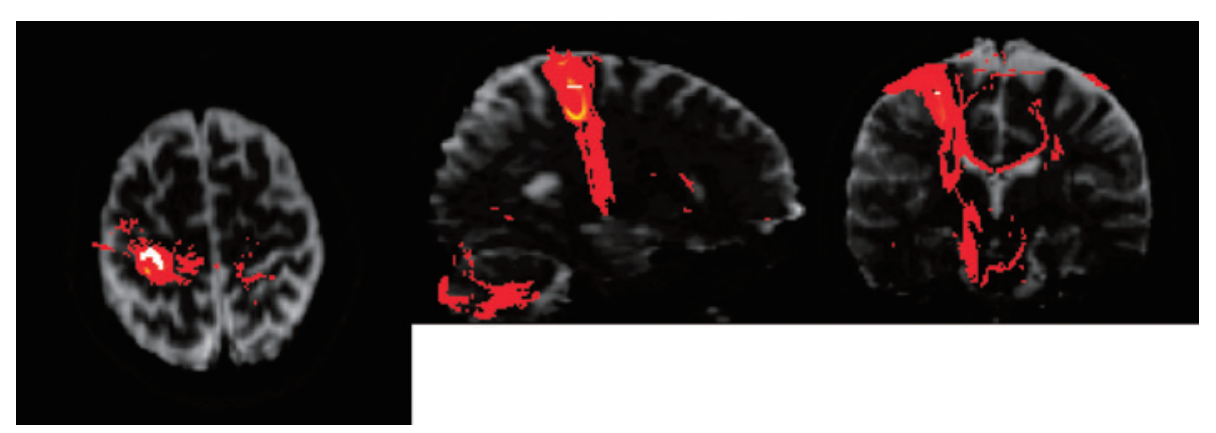

図 1. 拡散強調画像による神経走行の画像化

FSL というソフトウエアによって, 運動野から下向する線維や対側に広がる線維が分かる.81 方向の拡散強調画像から計算したもの. 正常男性, 37 歳.

また, 1990 年ころから, 画像の統計学的検討 が行われるようになり, 画像の解析を脳全体の 画素ごとに行うことができるようになった. 3 次元画像が撮像されるようになり, その画像を もとに脳全体を対象に血流や代謝の変化を，明 らかにすることができるようになったので，関 心領域など, 研究者の主観が入らない画像解析 が可能になり,さらに, 脳の形態を基準脳に変 形して一つの基準的な脳の座標で多数の被験者 のデー夕を解析できることになった。 このよう なソフトウエアには, SPM (statistical parametric mapping) ${ }^{2)}$ や 3DSSP (three dimensional stereotactic surface projection) $)^{3)}$ と呼ばれるもの があり, 無料で配布されている.これらも, 画 像研究に大きな貢献をしている.

\section{MRI (magnetic resonance imaging) に よる研究}

近年, MRIに関する研究が進展し, PET (positron emission tomography)でしかわからなかっ たような分野まで高解像度のMRIの画像で解析 できるようになり，また，他の検査法では知る ことができない, 神経線維の走行までも画像と してとらえられるようになっだ（図 1).このよ うな画像は, 拡散強調画像 (DWI) で得られる 組織内の水の動きを捉えることで可能になり,
特に一般臨床では, 脳梗塞の早期診断や Creutzfeldt-Jakob病などの診断に幅広く行われ ているが, 脳研究のッールとしても最先端のデー 夕を得ることができる機器になっている．早期 脳梗塞では, アストロサイト内に水が増加する ので, DWIで高信号域として診断できる5). また, 手術中に重要な機能をもつ, 視覚野への投射線 維, 錐体路などを脳外科手術前に拡散強調画像 によるトラクトグラフィー (DTI) で確認し, 病 巣との位置関係を明確にすることで, 手術後の 後遺症を最小限に抑えることを可能にした ${ }^{6)}$.さ らに，硬膜下電極を留置した症例で，皮質間の 電気刺激による誘発電位とその部位間の神経線 維の結合を, 詳細に検討しているところである. このようなデータは, 生きたヒトでこれまで知 ることができなかったものであったので, これ らの研究から, 新たな知見が見いだされること が期待される.

脳の機能を正確に捉えるには, 画像だけでは 時間分解能が低く, ミリ秒単位の神経細胞の活 動を捕らえることはできない. そのため, 脳磁 図や経頭蓋磁気刺激法 (TMS) など, 新しい電 気生理学的手法が考案され, 画像によるデー夕 との組み合わせによって, 正確な時間的・空間 的機能分布とその相互関連が解明されるように なっている. 特に, MRIと脳波との同時計測, MRI装置内でのTMSの開発などが行われ, 神経 

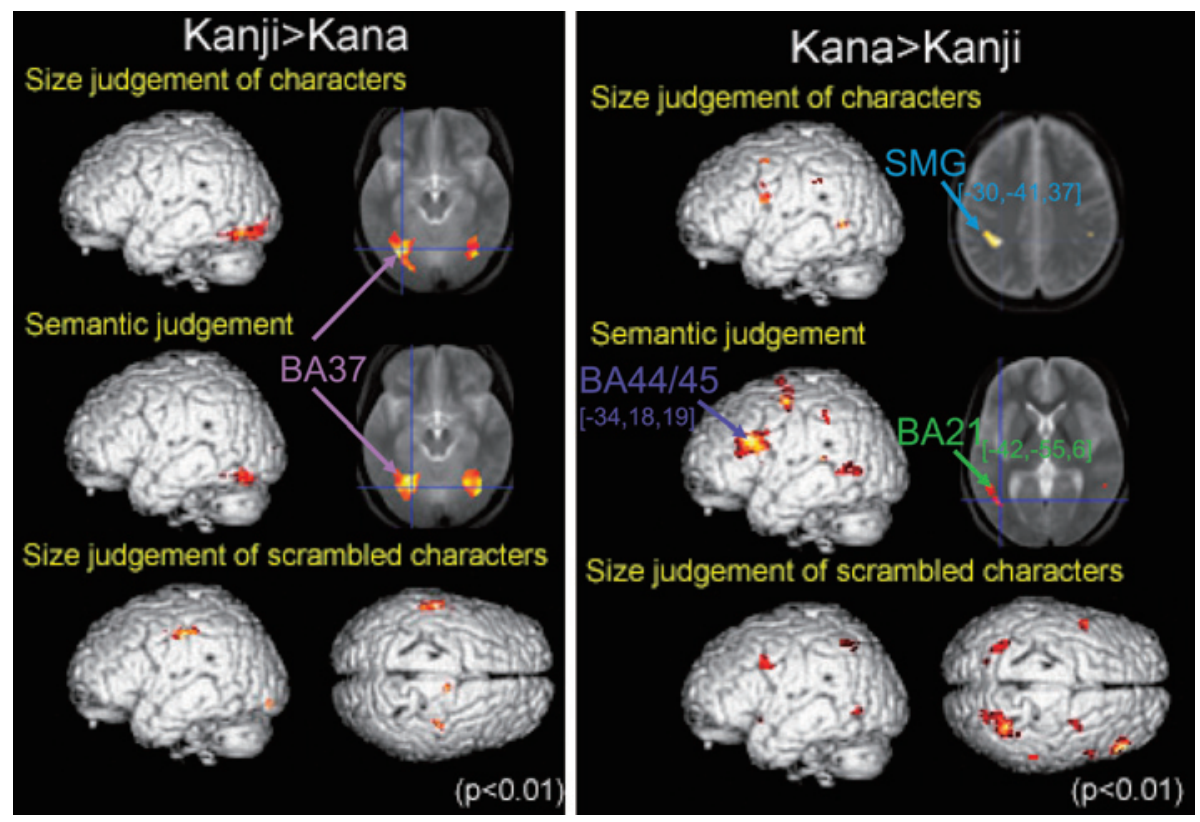

図 2. ヒトの言語負荷

漢字とひらがなを見せ, 脳の賦活部位を比較した. 左図は, 漢字の読字, 右図は, ひらがなの読 字の時に賦活される部位. 漢字は, 側頭葉下面, ひらがなは, 頭頂葉に賦活が強い.

生理学的な現象を画像と同時計測することで, 時間分解能と空間分解能の両面から精密に検討 することができるようになっており，今後，こ のような手法による研究が進展するものと考え られる。

これらの方法の応用として, 多角的アプロー チによる言語機能の解析データについて, 脳機 能研究の現状について例を挙げて説明する.

日本語は，独特の文字体系を有している。 大 きく，意味を持たず音だけを表す「かな」と意 味を持つ表意文字の「漢字」があり，「かな」に は「ひらがな」と「かたかな」がある。これら をなんの困難もなく使いこなせることは，表音 文字だけの言語に比べ，どのような違いがある か, 極めて興味ある課題である.ささらに, ヒト 脳は言葉を見ると，書かれたものを読まないよ うに指示を与えても，脳の言語野と言われてい るBroca野, Wernicke野などに神経細胞の賦活が 見られる。また, 漢字と「かな」では, 視覚野 で見た情報処理が異なっており，漢字は比較的
側頭葉の下部を，「かな」は比較的上部を通って 頭頂側頭葉につながっている7)(図 2).これまで, 発語に関する研究は, 充分行われているとは言 えないが, ロンドンの神経学研究所のPrice博士 などとの共同研究では, 2 力国語を話す, いわゆ るbilingualのヒトの言語コントロールに, 左大脳 基底核の前部（尾状核）が関与していることが 明らかになった8). 以上の研究から, 言語機能は 単に大脳皮質に限局した機能ではなく，おそら く, 動物などにおける個体間の連絡のための手 段，たとえば，ミラーニューロンのようなもの， が高度化して発達したものである可能性が考え られる。

また，漢字の読字には側頭葉の下部が重要な 役割をもっていることが, われわれのTMSやfunctional MRI（fMRI）の研究で明らかになってき ている ${ }^{9)}$.この側頭葉下面は, 形を認識してその 情報をもとに，音韻や意味を明らかにするのに 重要な㗢きをしていると考えられるが, 必ずし も象形文字でなくても，音韻文字においても同 


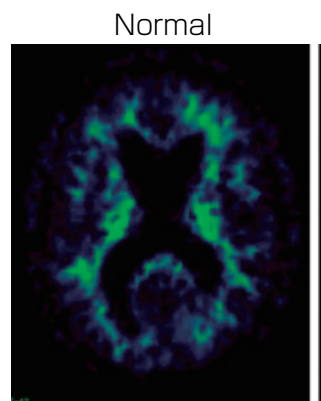

MMSE 28

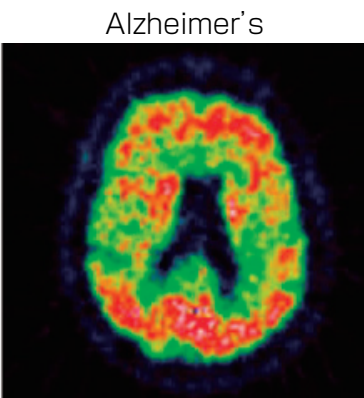

MMSE 20
AmnesticMCl

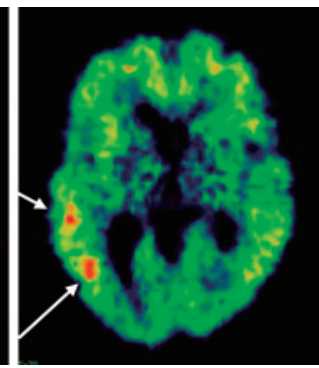

MMSE 27

図 3.PIB の画像（アミロイドイメージング）

左から正常, 中央は Alzheimer 病, 右は軽度認知障害. MMSE (mini-mental state examination）は正常と軽度認知障害で差はないが, 明らかに側頭葉などにアミロイドの沈着が見られる.

(D. Brooks 博士による)

様の所見が見られるので, 簡単に結論は出しに くい.しかし，言語機能に重要な部位であるこ とは明らかである。

機器の発達, たとえば, MRIが 1.5 テスラから 3 あるいは 7 テスラと高磁場化し, 信号強度が強 くなるに従って, 正確な部位の判断, 賦活部位 の同定が可能になり，また，神経線維結合が詳 細に検討されるようになると，これまでの神経 解剖学や神経病理学で得られた知識を確認する だけではなく，新たな脳機能の神経回路，機能 局在などが解明され, さらに, 脳の微細な活動 をも画像として捕らえられる可能性があり, そ れらによる脳機能の理解の進歩は, 特に, 前頭 葉を中心とした，こころの研究に多大な貢献を することになると期待される.

\section{PETによる研究}

PETは，ポジトロン（陽電子）の崩壊に伴う 2 つの高エネルギー放射線を測定して, 画像化す るものである. また, ポジトロンの特性として, 短寿命（半減期は酸素 15 で 120 秒, フッ素 18 で 110 分程度）なため, 被験者の被爆を最小限 に抑えることができ，さらに，ポジトロンを放 出する $\beta$ 崩壊は炭素, 酸素, 窒素など, 生体構成 分子であるため, 体内の代謝を乱すことなく,
測定が可能であるという点である. 近年の機器 の発達で,これまで悪かった空間分解能が $2 \mathrm{~mm}$

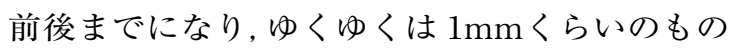
ができるようになると思われる.

脳血流量などは, MRIでも測定可能であるが, PETでは神経伝達物質やその受容体, あるいは, 脳内に蓄積する物質の画像化ができるので，た とえば, Alzheimer病における $\beta$ アロイド蛋白 などが炭素 11 で標識されたピッツバーグコンパ ウンドB (PIB) で, 比較的簡単に見ることがで きるようになり ${ }^{10)}$ (図 3), 今後のAlzheimer病の 診断の重要な進歩の一歩になると考えられる. 現在, 脳内の炎症性疾患で増える活性化ミクロ グリアが末梢性のベンゾディアゼピン受容体を 持っているため, PK11195 というトレーサーで 画像化が可能で, Alzheimer病の炎症性変化が描 出できる ${ }^{11)}$ (図 4).このような病態がどのように アミロイド蛋白の蓄積や神経原線維変化と関連 しているか, 今後の重要な研究テーマとなると 思われる。

さらに, 現在,アメリカのNIH を中心として, Alzheimer Disease Neuroimaging Initiative (ADNI) という，MRI，PETなどを使った多施 設研究が世界規模で始まっており，MRIによる 海馬などの萎縮以外に, ブドウ糖代謝, PIBなど のアミロイドイメージングなどさまざまなバイ 

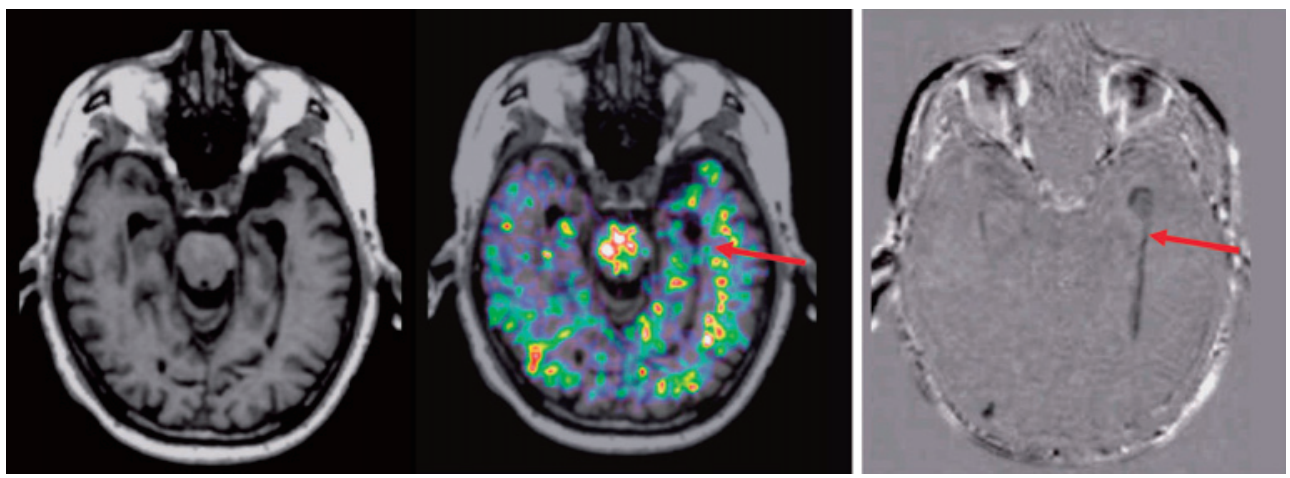

図 4. PK 11195 の画像（炎症細胞のイメージング）

Alzheimer 病により, 側頭葉の萎縮の強い部分で（右端）, PK 11195 の集積が多いことがわ かる. (R. Banati 博士による)

オマーカー探しを含めた研究がこれから活発に なるところで, 治療方法の開発とともに, 病態 の把握という点からも, PETをはじめとする神 経画像の研究がますます重要性を増す可能性が ある. 当然, これらの発展の基礎には, マイク ロプロセッサーなど電子機器の発達があること は言うまでもない.

\section{おわりに}

MRI，PETによる脳機能画像について，それ ぞれの特徵ある機能画像を提示し，それぞれの 特徵を述べた，MRIは，発展途上で，今後さら に高磁場化し，さまざまな生体情報を得ること ができるようになると思われる，PETは，解像 度では劣るが, MRIよりも感度が高く, 脳内の さまざまな物質の探索に有用であり, 今後は,

PETでの研究成果が，MRIに反映されていくよ うになると推測される.

脳神経科学の分野における脳機能画像の研究 では，日本は世界から立ち後れている感は否め ない.しかし，それを臨床医学に応用すること では, 分子プローブの開発も含めて, 決して世 界に立ち後れた状態にはない。 むしろ, 撮像機 器の開発において, 大きなハンディを背負って いると言わざるをえない.いずれにしても，こ
れから, ADNIのように心理検査だけではなく, バイオマーカーを必要とする疾患の診断に, 広 い意味での脳の画像診断が重要になってくるこ とは, 言をまたない. 今後, 多くの若い研究者 が脳機能画像研究に参画し, 大きな発展を遂げ ることを期待したい.

\section{文献}

1) Roy CS, Sherrington CS: On the regulation of the bloodsupply of the brain. J Physiol $11: 85-158,1890$.

2) Friston KJ, et al: Comparing functional (PET) images: the assessment of significant change. J Cereb Blood Flow Metab 11 : 690-699, 1991.

3) Minoshima S, et al: Anatomic standardization:linear scaling and nonlinear warping of functional brain images. J Nucl Med 35 : 1528-1537, 1994.

4) Fushimi $Y$, et al:Fractional anisotropy and mean diffusivity : comparison between 3.0-T and 1.5-T diffusion tensor imaging with parallel imaging using histogram and region of interest analysis. NMR Biomed 2007 (in press)

5) Sorensen AG, et al: Hyperacute stroke : evaluation with combined multisection diffusion-weighted and hemodynamically weighted echo-planar MR imaging. Radiology 199: 391-401, 1996.

6) Okada T,et al:Corticospinal tract localization:integration of diffusion-tensor tractography at 3-T MR imaging with intraoperative white matter stimulation mapping-preliminary results. Radiology $240: 849-857,2006$.

7) Thuy DH, et al : Implicit and explicit processing of kanji and kana words and non-words studied with fMRI. Neuroimage 23 : 878-889, 2004.

8) Crinion J, et al : Language control in the bilingual brain. 
Science 312 : 1537-1540, 2006.

9) Usui K, et al : Processing of Japanese morphogram and syllabogram in the left basal temporal area:electrical cortical stimulation studies. Brain Res Cogn Brain Res 24 : 274-283, 2005.
10) Nordberg A : PET imaging of amyloid in Alzheimer's disease. Lancet Neurol $3: 519-527,2004$.

11) Cagnin $\mathrm{A}$, et al: In-vivo measurement of activated microglia in dementia. Lancet 358 : 461-467, 2001. 